\title{
Pectic Enzymes of Pigmented Strains of Clostridium
}

\author{
By BARBARA M. LUND AND T. F. BROCKLEHURST \\ A.R.C. Food Research Institute, Colney Lane, Norwich, NR4 7 UA
}

(Received 22 June 1977)

\begin{abstract}
The pectic enzymes of six strains of pigmented, pectolytic clostridia isolated from potatoes were examined and compared with those strains of Clostridium felsineum and Clostridium aurantibutyricum using cup-plate assays. The organisms could be divided into two groups. Group I consisted of the potato isolates and the strain of $C$. aurantibutyricum; these formed pectic lyase enzymes and pectinesterase but no pectic hydrolase. Group 2 consisted of eight strains of $C$. felsineum (and one culture labelled Clostridium roseum); these formed pectic lyase and pectic hydrolase but no detectable pectinesterase. Viscometric studies and analyses of degradation products of pectate formed by enzymes of four representative strains from group I and two strains from group 2 showed that all these clostridia formed endopectate lyase enzymes; studies of one enzyme preparation showed that the $\mathrm{pH}$ optimum was about 9.5 . In addition, the group 2 organisms formed endopolygalacturonase and probably also exopolygalacturonase.
\end{abstract}

\section{INTRODUCTION}

During studies of bacterial soft rot of potatoes, pectolytic clostridia have regularly been detected in rotting tissue (Lund, 1972; Lund \& Kelman, 1977). Although the primary cause of this spoilage is usually Erwinia carotovora, some of these pectolytic clostridia cause rapid maceration of potato tissue and undoubtedly enhance the effect of E. carotovora (Rudd-Jones \& Dowson, 1950). The pectolytic clostridia associated with rotting potatoes probably belong to several species (Lund, I972) and include a group of bacteria which form a pink pigment. Apart from the colour of the pigment, these clostridia have many properties in common with Clostridium felsineum (B. M. Lund \& G. M. Wyatt, unpublished). The purpose of this work was to determine whether pigmented clostridia isolated from potatoes differed from C. felsineum or another pigmented clostridium, Clostridium aurantibutyricum, in the type of pectic enzymes formed.

Of the bacterial enzymes which depolymerize pectic substances, the most widely reported are those with lyase activity, although bacteria from several genera form enzymes which hydrolyse pectate (see Rombouts, I972; Rombouts \& Pilnik, 1972; Fogarty \& Ward, 1974). Species of Arthrobacter, Bacillus, Erwinia, Pseudomonas and Xanthomonas form endopectate lyases [EC 4.2.2.2; poly(I,4- $\alpha$-D-galacturonide) lyase] with $\mathrm{pH}$ optima between $8 \cdot 0$ and 9.6 which usually show a requirement for calcium ions. A strain of Erwinia aroideae (E. carotovora) and Clostridium multifermentans form exopectate lyases [EC 4.2.2.9; $\operatorname{poly}(\mathrm{I}, 4-\alpha-\mathrm{D}-$ galacturonide) exo-lyase] with $\mathrm{pH}$ optima of $8 \cdot 0$ to $8 \cdot 5$; the enzyme from $E$. aroideae did not require calcium ions. Species of Erwinia and Pseudomonas form endopolygalacturonases [EC 3.2. I . I 5; poly (I,4- $\alpha$-D-galacturonide) glycanohydrolase] with pH optima of $5 \cdot 2$ to $5 \cdot 4$, and an exopolygalacturonase [EC 3.2.I.82; poly( $\mathrm{I}, 4-\alpha$-D-galactosiduronate) digalacturonohydrolase] has been isolated from $E$. aroideae. Activity of these hydrolytic enzymes was not dependent on calcium ions. Formation of pectinesterase (EC 3.I.I.II; pectin pectylhydrolase) active at $\mathrm{pH} 7 \cdot 0$ has been reported for strains of Arthrobacter, Bacillus, Clostridium and Erwinia. 
The work reported here showed that when grown in potato tissue, strains of pigmented clostridia isolated from potatoes and C. aurantibutyricum NCIBI0659 formed endopectate lyase and pectinesterase. These organisms differed in this respect from strains of $C$. felsineum which formed endopectate lyase, endopolygalacturonase and possibly exopolygalacturonase but no detectable pectinesterase.

\section{METHODS}

Materials. Sodium pectate (sodium polypectate, Exchange Brand, product no. 6024) and pectin N.F. (U.S. National Formulary, $68 \%$ esterified) were obtained from Sunkist Growers Inc., Ontario, California, U.S.A. The moisture content of the sodium pectate was estimated to be $1 \mathrm{I} \cdot 7 \%$ by drying to constant weight at $110{ }^{\circ} \mathrm{C}$. Polygalacturonic acid was obtained from Sigma. The sample of trigalacturonic acid used as a chromatographic marker was supplied by Dr F. M. Rombouts. Thiomersal, the sodium salt of ethyl mercurithiosalicylic acid, was obtained from BDH.

Bacteria. The cultures are listed in Table I. The first group, with the prefix BL, was isolated from rotting potatoes. The first four isolates formed pink colonies and their characterization will be reported later; isolate BL74/100 also formed pink colonies and BL75/13 formed yellow colonies. The remaining cultures were obtained from the National Collection of Industrial Bacteria. The cultures were maintained in potato infusion medium to which was added $0.05 \%(\mathrm{w} / \mathrm{v})$ cysteine. $\mathrm{HCl}$ (Lund, 1972), and subcultured monthly. Stock cultures were also freeze-dried. The purity of cultures was checked by repeated streaking on to a potato infusion agar incubated aerobically or under $\mathrm{H}_{2} / \mathrm{CO}_{2}(90: 10, \mathrm{v} / \mathrm{v})$. Incubation was at $25^{\circ} \mathrm{C}$ for the isolates from potatoes, and at $30^{\circ} \mathrm{C}$ for $C$. felsineum and C. aurantibutyricum.

\section{Production of pectic enzymes}

Growth of clostridia in potato tissue. Cultures were grown in aseptically prepared, raw potato tissue immersed in a sterile $0.05 \%(\mathrm{w} / \mathrm{v})$ solution of cysteine. $\mathrm{HCl}$. Potatoes were peeled, immersed in ethanol and flamed to sterilize the outer surface; this charred the outer tissue of the tubers. A cylinder of tissue $(\mathrm{I} \cdot 2 \mathrm{~cm}$ diam.) was removed aseptically using a sterile cork-borer, a $\mathrm{I} \mathrm{cm}$ length from the end was discarded and a $3.5 \mathrm{~cm}$ length of the remaining tissue was transferred to a wide-necked $25 \mathrm{ml}$ bottle containing $15 \mathrm{ml}$ sterile $0.05 \%(\mathrm{w} / \mathrm{v})$ cysteine. $\mathrm{HCl}$ solution previously heated for $30 \mathrm{~min}$ to expel dissolved oxygen and cooled. Each bottle was inoculated with 0.3 to $0.5 \mathrm{ml}$ of a 4-day-old culture of the required organism in VL medium (Barnes, Impey \& Goldberg, 1966). For each organism, a set of five inoculated bottles and one uninoculated bottle, was incubated at $25^{\circ} \mathrm{C}$ for up to 5 days. After incubation, samples from the bottles were tested for purity. Occasionally growth of low numbers of non-pectolytic contaminating bacteria occurred in the inoculated or control uninoculated cultures, but no breakdown of tissue occurred in the control bottles and any contamination was judged to be insignificant. After 5 days, or earlier if the majority of the potato tissue was degraded, the remainder of the tissue was dispersed by agitation or, in the case of the culture which failed to cause maceration, the tissue was macerated mechanically. The five cultures for each organism were pooled and the large debris was removed by centrifuging ( $2000 \mathrm{~g}$, $10 \mathrm{~min}$ ). The liquid was decanted and centrifuged ( $32000 \mathrm{~g}, 5{ }^{\circ} \mathrm{C}$, 10 $\mathrm{min}$ ). The supernatant liquid was decanted, mixed and dialysed twice at $\mathrm{I}{ }^{\circ} \mathrm{C}$ against 50 vols distilled water for $24 \mathrm{~h}$. The resulting enzyme preparations were stored at $-20^{\circ} \mathrm{C}$.

Growth of Clostridium $\mathrm{BL} 7 \mathrm{O} / 2 \mathrm{O}$ in pectate medium. The growth medium contained $\left(\mathrm{g}^{-1}\right)$ : polygalacturonic acid, 5 ; yeast extract (Difco), $5 ; \mathrm{Na}_{2} \mathrm{HPO}_{4} .2 \mathrm{H}_{2} \mathrm{O}, 7 \cdot 2 ; \mathrm{KH}_{2} \mathrm{PO}_{4}, 3 \cdot 5$; cysteine. $\mathrm{HCl}, 0 \cdot 5$; plus approx. I I $\mathrm{ml}$ $2 \mathrm{M}-\mathrm{NaOH}$; the $\mathrm{pH}$ was adjusted to $7^{\circ} \circ$ to $7^{\circ} \mathrm{I}$. The medium $(900 \mathrm{ml})$ was placed in a $\mathrm{I} 1$ conical flask and sterilized by autoclaving. Stoppers with inlet and outlet tubes were sterilized separately and fitted to the flask immediately after autoclaving. During cooling, a slow stream of $\mathrm{H}_{2} / \mathrm{CO}_{2}(90: \mathrm{IO}, \mathrm{v} / \mathrm{v})$ was passed through the medium. After inoculation with $\mathrm{IO} \mathrm{ml}$ of a culture in potato infusion medium, the gas inlet tube was closed and a Bunsen valve was attached to the outlet tube to allow escape of gases formed during growth. After incubation at $25^{\circ} \mathrm{C}$ for 4 days, cultures were harvested by centrifuging $\left(23000 \mathrm{~g}, 3^{\circ} \mathrm{C}, 2 \mathrm{~h}\right)$ and the supernatant liquid was stored at $-20^{\circ} \mathrm{C}$. Before assaying enzyme activity the liquid was dialysed twice at $\mathrm{I}{ }^{\circ} \mathrm{C}$ against 50 vols distilled water for $24 \mathrm{~h}$.

\section{Assay of pectic enzymes}

Cup-plate assays of hydrolases and lyases. The method used was based on that of Dingle, Reid \& Solomons (1953) for polygalacturonase. To assay hydrolase activity a pH of 5.2 was used. The gel contained $(\%, \mathrm{w} / \mathrm{v})$ : sodium pectate or pectin N.F., I; ammonium oxalate, $0^{\circ} 5$; thiomersal, $0^{\circ} \mathrm{OI}$ (as preservative); Ionagar no. 2 (Oxoid), $1 \cdot 5$; and $0.2 \mathrm{M}$-sodium acetate buffer, $\mathrm{pH} 5 \cdot 2$. The ammonium oxalate was included to complex divalent cations, particularly calcium. Preliminary tests using dialysed culture liquid of $E$. carotovora as a source of polygalacturonase and pectate lyase enzymes, showed that adding ammonium oxalate to the medium used for the hydrolase assay had no effect on the diameters of zones formed, but when added to the 
medium used for the lyase assay, it inhibited enzyme activity. Lyase activity was assayed at $\mathrm{pH} 8.6$ in the presence of calcium ions. The gel contained $\left(\%\right.$, w/v): sodium pectate or pectin N.F., I; $\mathrm{CaCl}_{2} .6 \mathrm{H}_{2} \mathrm{O}, 0.002$; thiomersal, o.oI ; Ionagar no. 2, I.5; and o. I M-Tris/ $\mathrm{HCl}$ buffer, $\mathrm{pH} 8 \cdot 6$. Standard volumes ( $15 \mathrm{ml}$ ) of molten assay medium were poured into Petri dishes $(9 \mathrm{~cm}$ diam.) and, after solidification, the open plates were dried at $52{ }^{\circ} \mathrm{C}$ for $45 \mathrm{~min}$. Cups $(8 \mathrm{~mm}$ diam.) were cut from the agar medium with a cork-borer and filled with $100 \mu \mathrm{l}$ of enzyme preparation. After incubation at $30^{\circ} \mathrm{C}$ for $24 \mathrm{~h}$ breakdown of substrate was detected by flooding the plates with $5 \mathrm{M}-\mathrm{HCl}$ which precipitated undegraded polymer. The results were recorded as the diameter of the cleared zone minus the diameter of the cup. Each enzyme preparation was tested in duplicate on each of two plates.

Cup-plate assay of pectinesterase. The method was based on that of McComb \& McCready (1958) except that cups were made in the agar, as in the assays for hydrolase and lyase, instead of using filter-paper discs. The gel contained $(\%, \mathrm{w} / \mathrm{v})$ : pectin N.F., I; thiomersal, o.0I ; Ionagar no. $2, \mathrm{I} \cdot 5$; and either $\mathrm{O} \cdot 2 \mathrm{M}$-sodium phosphate buffer, $\mathrm{pH} 7 \cdot 0$, or $\mathrm{o} \cdot 2 \mathrm{M}$-Tris/HCl buffer, $\mathrm{pH} 8 \cdot 6$. Before addition to the cups, enzyme preparations were adjusted to $\mathrm{pH} 7.0$ using a few drops of $0.1 \mathrm{M}-\mathrm{NaOH}$ to avoid non-enzymic de-esterification of the substrate (Abdel-Fattah, Mabrouk \& Edrees, 197I). After incubation of plates at $30{ }^{\circ} \mathrm{C}$ for $24 \mathrm{~h}$, areas of deesterified substrate were detected as described by McComb \& McCready (1958) and appeared as cleared zones against a red background. The results were recorded as for the hydrolase and lyase enzymes.

Viscometric assays of hydrolase and lyase activity. The change in viscosity of reaction mixtures at $30^{\circ} \mathrm{C}$ was measured in suspended level viscometers (nominal constant $0.03 \times 10^{-6} \mathrm{~m}^{2} \mathrm{~s}^{-2}$ ) with a water flow time of about $26 \mathrm{~s}$. The reaction mixture for assay of hydrolase activity contained: sodium pectate or pectin N.F., $0.3 \%$ $(\mathrm{w} / \mathrm{v}) ; \mathrm{NaCl}, 0 . \mathrm{I} \mathrm{M}$; and $0.025 \mathrm{M}$-sodium acetate buffer, pH 5.2 (Nasuno \& Starr, I966). For most of the assays of lyase activity the reaction mixture contained: sodium pectate or pectin N.F., $0.25 \%(\mathrm{w} / \mathrm{v})$; $\mathrm{CaCl}_{2} .2 \mathrm{H}_{2} \mathrm{O}, 0.25 \mathrm{~mm}$; and $0.05 \mathrm{M}$-Tris/HCl buffer, $\mathrm{pH} 8.6$ (Moran, Nasuno \& Starr, 1968); to correlate the change in viscosity with increase in unsaturated and reducing groups the concentrations of sodium pectate and $\mathrm{CaCl}_{2} .2 \mathrm{H}_{2} \mathrm{O}$ were increased to $0.5 \%(\mathrm{w} / \mathrm{v})$ and $0.4 \mathrm{mM}$ respectively. The results are expressed as percentage change in viscosity (Roboz, Barratt \& Tatum, 1952) or in terms of enzyme activity in viscometric units [I unit is defined as the enzyme activity giving a $50 \%$ reduction in relative viscosity in I min (Nagel \& Vaughn, I962)]. To determine the effect of $\mathrm{pH}$ on degradation of pectate by an enzyme preparation from Clostridium $\mathrm{BL} 7 \mathrm{O} / 2 \mathrm{20}$, the buffers used (Gomori, 1955 ) were: $0.025 \mathrm{M}$-sodium acetate, $\mathrm{pH} 5.0$ and $5.5 ; 0.05 \mathrm{M}$ sodium phosphate, $\mathrm{pH} 6.0$ to $7.5 ; 0.05 \mathrm{M}-\mathrm{Tris} / \mathrm{HCl}, \mathrm{pH} 7.5$ to $8.5 ; 0.05 \mathrm{M}$-glycine/NaOH, pH 9.0 to 10.5 .

\section{Studies of reaction products}

Reaction mixtures without enzyme were prepared in duplicate flasks at $30{ }^{\circ} \mathrm{C}$. Immediately after addition of the enzyme preparation, a sample $(\mathrm{I} 2 \mathrm{ml})$ from one flask was transferred to a viscometer at $30^{\circ} \mathrm{C}$ and the reaction was followed by measuring the change in viscosity. Samples from the duplicate flask were used to measure the formation of unsaturated compounds, of reducing groups and for paper chromatography.

Assay of unsaturated products. Samples from reaction mixtures were suitably diluted with O-I M-sodium acetate buffer, $\mathrm{pH} 3.7$, and $E_{235}$ was measured. The concentration of unsaturated groups was calculated assuming an $\epsilon_{235}$ of $4800 \mathrm{l} \mathrm{mol}^{-1} \mathrm{~cm}^{-1}$ for unsaturated digalacturonic acid (Macmillan \& Vaughn, I964; Rombouts \& Pilnik, 1972).

Assay of reducing groups. The method of Jansen \& MacDonnel (1945) was used, except that the iodine solution was $0.025 \mathrm{M}$ and liberated iodine was titrated with $0.0125 \mathrm{M}$-sodium thiosulphate in the presence of $10 \mathrm{ml}$ of a solution containing $0.5 \%(\mathrm{w} / \mathrm{v})$ of both cadmium acetate and potassium iodide, in order to convert the iodide ion to the more stable cadmium iodide complex and so decrease oxidation by atmospheric oxygen (Swoboda \& Lea, 1958).

Percentage degradation of sodium pectate. The approximate percentage degradation of sodium pectate was calculated from the unsaturated or reducing groups formed. The calculations were based on an estimated moisture content of $\mathrm{II} \cdot 7 \%$, and the assumptions that the galacturonic acid content was $85 \%$ of the dry weight and that the final degradation products were the saturated or unsaturated dimer.

Analysis of degradation products by paper chromatography. The methods were based on those of Rombouts (1972). Sufficient enzyme was used to give a $50 \%$ decrease in viscosity of the reaction mixture within 20 to $30 \mathrm{~min}$. Samples were removed from the reaction mixture after $2.5 \times$ and $15 \times$ the time required for a $50 \%$ decrease in viscosity, and after $24 \mathrm{~h}$. The samples were heated for 20 min in a bath of boiling water to inactivate the enzymes, and 2 vols ethanol were added to precipitate high molecular weight material. After $30 \mathrm{~min}$ at room temperature the precipitate was removed by centrifuging $\left(23000 \mathrm{~g}, 30 \mathrm{~min}, 3{ }^{\circ} \mathrm{C}\right)$. The supernatant liquid was concentrated by evaporation under reduced pressure at $40^{\circ} \mathrm{C}$. The degradation products were converted to their free acids by adding I $\mathrm{g}$ Dowex $50 \mathrm{~W}-\mathrm{X} 8,20$ to $50 \mathrm{U}$.S. mesh in the $\mathrm{H}^{+}$form; after $10 \mathrm{~min}$ at room temperature the resin was filtered off and washed with a volume of glass-distilled water equal to the sample volume. The samples were finally evaporated under reduced pressure to give a 6- or 20 -fold concentration of the volume of the original sample. The degradation products of pectate were 
separated by descending chromatography on Whatman no. 4 paper. Solvent systems used were ethyl acetate/ pyridine/water/acetic acid (5:5:3:I, by vol.) (Hasegawa \& Nagel, 1962; Rombouts, 1972) for samples containing both saturated and unsaturated compounds, and butanol/acetic acid/water (2:I:I, by vol.) (Horikoshi, 1972) for samples containing only saturated compounds. Saturated monogalacturonic acid and trigalacturonic acid were used as markers and chromatograms were developed for $7 \mathrm{~h}, 3 \mathrm{I} \mathrm{h}$ or, occasionally, for $55 \mathrm{~h}$.

To examine products resulting from lyase activity, duplicate chromatograms were prepared. One was loaded with $50 \mu \mathrm{l}$ of 6-fold concentrated samples and was stained with $\mathrm{AgNO}_{3}$ (Trevelyan, Procter \& Harrison, 1950) to detect reducing compounds; the other was loaded with $50 \mu \mathrm{l}$ of 20 -fold concentrated samples and was stained by the thiobarbituric acid method of Warren (1960) to detect unsaturated oligogalacturonic acids. To examine products resulting from hydrolase activity, chromatograms were stained by the $\mathrm{AgNO}_{3}$ method. The identity of oligogalacturonic acids was determined from their $R_{\text {GalA }}$ values (distance migrated relative to that of saturated galacturonic acid). The $R_{\mathrm{GalA}}$ values (based on the mean value from three chromatograms developed for $30 \mathrm{~h}$ ) of degradation products of pectate after chromatography in ethyl acetate/pyridine/water/acetic acid $(5: 5: 3: \mathrm{I}$, by vol.) for $30 \mathrm{~h}$ were: unsaturated dimer, $0.45 ;$ unsaturated trimer, 0.11 ; unsaturated tetramer, 0.04 ; saturated dimer, 0.21 ; saturated trimer, 0.06 . These values are similar to those reported by Rombouts (1972). After $55 \mathrm{~h}$ development the saturated tetramer showed a mobility of 0.6 relative to that of the saturated trimer. The $R_{\mathrm{GaIA}}$ values of saturated degradation products after chromatography in butanol/acetic acid/water $(2: \mathrm{I}: \mathrm{I}$, by vol.) for $26 \mathrm{~h}$ were: dimer, 0.56 ; trimer, 0.30 ; tetramer, 0.14 ; pentamer, 0.06 ; hexamer, 0.02 .

\section{RESULTS}

\section{Pectic enzymes formed by pigmented pectolytic clostridia grown in potato tissue}

When plated on pectate medium (Lund, 1972) and incubated under $\mathrm{H}_{2} / \mathrm{CO}_{2}(90: 10, \mathrm{v} / \mathrm{v}$ ), all the clostridia tested except one liquefied the pectate and disintegrated the cylinder of potato tissue. The exception was $C$. roseum NCIBI I I 2 I which failed to form pigment and appeared not to be a typical strain (see Breed, Murray \& Smith, 1957). The most active cultures were some strains of $C$. felsineum and the strain of $C$. aurantibutyricum which caused complete breakdown in 3 days; the least active culture, BL $72 / 60$, only caused slight disintegration in 5 days. [There is some doubt as to the identity of the strain of $C$. aurantibutyricum which was the only one available. It failed to form pigment and rapidly macerated potato tissue, whereas the original isolate had a pinkish to reddish pigment on nutrient agar and an orange to reddish one on maize or potato mashes, and failed to disintegrate potato tissue despite a reported ability to utilize pectin (Hellinger, 1947).]

The assays (Table I) showed a difference between the pectic enzymes formed by the potato isolates of clostridia and by $C$. aurantibutyricum, and those formed by cultures of C. felsineum. Enzyme preparations from the potato isolates of clostridia and from C. aurantibutyricum contained pectic lyase enzymes, active at $\mathrm{pH} 8 \cdot 6$, and pectinesterase but no detectable pectic hydrolase. In contrast, the enzyme preparations from $C$. felsineum

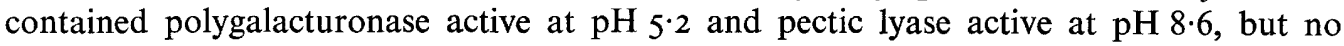
detectable pectinesterase. No pectic enzyme activity could be detected in the preparation from C. roseum NCIBI I I I grown in potato tissue.

In further work, enzymes formed by representative strains were examined in more detail. Viscometric assays of enzymes from strains BL70/20, BL72/60, BL72/6I, C. aurantibutyricum NCIB I 0659, $C$. felsineum $\mathrm{NCIB9540}$ and $C$. felsineum $\mathrm{NCIBI}$.0690 showed that activity at $\mathrm{pH} 8.6$ was $\mathrm{I}^{\cdot} 5$ to 3 times higher on pectate than on pectin N.F. For the two strains of $C$. felsineum, activity at $\mathrm{pH} 5.2$ was 4 to 6 times higher on pectate than on pectin. Thus the enzymes involved were probably pectate lyases and polygalacturonases.

Pectate lyase activity. The relationship between decrease in viscosity, increase in reducing groups and formation of unsaturated groups in the assay for pectate lyase activity of Clostridium BL70/20 is shown in Fig. I. Similar results were obtained with BL72/60, BL72/6I, C. aurantibutyricum NCIBI0659, C. felsineum NCIB9540 and NCIBI0690. The concentration of unsaturated groups formed was equal to the concentration of reducing groups, indicating that in this assay all the activity was due to lyase enzymes. At 50\% reduction in viscosity, 


\section{Table I. Assay of pectic enzymes by cup-plate methods}

Plates for hydrolase assay contained $(\%, w / v)$ : substrate, $\mathrm{I} \cdot 0$; ammonium oxalate, 0.5 ; thiomersal, $0.0 \mathrm{I}$; Ionagar no. 2, I.5; and 0.2 M-sodium acetate buffer, $\mathrm{pH} 5.2$. Plates for lyase assay contained $(\%, \mathrm{w} / \mathrm{v})$ : substrate, $\mathrm{I} \cdot 0 ; \mathrm{CaCl}_{2} \cdot 6 \mathrm{H}_{2} \mathrm{O}, 0.002$; thiomersal, $0.0 \mathrm{I}$; lonagar no. $2, \mathrm{I} \cdot 5$; and $0 . \mathrm{I} \mathrm{M}-$ Tris $\mathrm{HCl}$ buffer, $\mathrm{pH} 8 \cdot 6$. Plates for pectinesterase assay contained $(\%, \mathrm{w} / \mathrm{v})$ : pectin N.F., I.0; thiomersal, $0.0 \mathrm{I}$; Ionagar no. $2, \mathrm{I} \cdot 5$; and either $0.2 \mathrm{M}$-sodium phosphate buffer, $\mathrm{pH} 7 \cdot 0$, or $0.2 \mathrm{M}$-Tris $/ \mathrm{HCl}$ buffer, $\mathrm{pH} 8 \cdot 6$. Results are expressed as zone width $(\mathrm{cm})$ equal to the diameter of the cleared zone minus the cup diameter, and are the mean values of four assays on two plates.

\begin{tabular}{|c|c|c|c|c|c|c|}
\hline \multirow{2}{*}{$\begin{array}{l}\text { Culture supernatant } \\
\text { from: }\end{array}$} & \multicolumn{2}{|c|}{$\begin{array}{l}\text { Hydrolase assay } \\
\text { using: }\end{array}$} & \multicolumn{2}{|c|}{$\begin{array}{c}\text { Lyase assay } \\
\text { using: }\end{array}$} & \multicolumn{2}{|c|}{ Pectinesterase assay } \\
\hline & Pectate & Pectin & Pectate & Pectin & pH 8.6 & $\mathrm{pH} 7 \cdot 0$ \\
\hline \multicolumn{7}{|l|}{ Clostridium spp. } \\
\hline BL $70 / 20$ & 0 & 0 & $I \cdot 2$ & $I \cdot 2$ & 0.9 & 0.6 \\
\hline $\mathrm{BL} 72 / 60$ & 0 & 0 & 0.4 & $0 \cdot 2$ & 0 & 0.2 \\
\hline BL72/6I & 0 & 0 & 0.8 & 0.7 & 0.6 & 0.6 \\
\hline BL $73 / 46$ & 0 & 0 & $I \cdot O$ & $I \cdot I$ & 0.8 & 0.5 \\
\hline BL74/IOO & 0 & 0 & $I \cdot I$ & $I \cdot O$ & 0.8 & 0.6 \\
\hline BL75/I 3 & 0 & 0 & $1 \cdot 0$ & 0.9 & 0.9 & 0.5 \\
\hline \multicolumn{7}{|l|}{ C. aurantibutyricum } \\
\hline NCIBI0659 & 0 & 0 & $1 \cdot 2$ & $I \cdot O$ & 0.8 & $0 \cdot 3$ \\
\hline \multicolumn{7}{|l|}{ C. felsineum } \\
\hline NCIB9539 & 0.9 & 0 & $I \cdot 2$ & $\mathbf{I} \cdot \mathbf{I}$ & o & 0 \\
\hline $\mathrm{NClB} 9540$ & $I \cdot O$ & 0 & $1 \cdot 0$ & $I \cdot O$ & 0 & 0 \\
\hline NCIBI 10690 & $I \cdot I$ & 0 & $1 \cdot 1$ & $1 \cdot 1$ & 0 & 0 \\
\hline VPI-2744 & 0.6 & 0 & $I \cdot I$ & 0.9 & 0 & 0 \\
\hline VPI-2774 & $I \cdot O$ & 0 & $\mathrm{I} \cdot \mathrm{O}$ & 0.8 & 0 & 0 \\
\hline VPI-2779-I & $I \cdot 2$ & 0 & $I \cdot O$ & $1 \cdot 0$ & o & 0 \\
\hline VPI-2799 & 0.7 & 0 & $1 \cdot 0$ & $0 \cdot 8$ & 0 & 0 \\
\hline VPI-28O2 & $I \cdot I$ & 0 & 0.6 & 0.6 & 0 & 0 \\
\hline \multicolumn{7}{|l|}{ C. roseum } \\
\hline NCIB653 & $I \cdot 2$ & o & 0.8 & 0.7 & 0 & 0 \\
\hline NCIBII I 2 I & 0 & 0 & 0 & 0 & 0 & 0 \\
\hline
\end{tabular}

the percentage degradation of the substrate, calculated from the increase in $E_{235}$, was between 0.8 and $1.7 \%$ for the six cultures, indicating that in each case the reaction was due to endopectate lyase activity.

When samples from the reaction mixtures were chromatographed, low molecular weight oligomers were not detected in samples removed after a reaction time of $2.5 \times$ longer than that required for a $50 \%$ decrease in viscosity, when $\mathrm{I} \cdot 4$ to $4 \%$ of the pectate had been degraded. In later samples, when 12 to $23 \%$ of the pectate had been degraded, the products detected on chromatograms were the unsaturated and saturated tetramer and unsaturated trimer. In samples removed after incubation of the reaction mixture for $24 \mathrm{~h}, 30$ to $39 \%$ of the pectate had been degraded. In comparison with the preceding sample, chromatograms showed increased amounts of unsaturated and saturated tetramer and unsaturated trimer; with enzymes from BL70/20, BL72/60 and C. aurantibutyricum small amounts of saturated and unsaturated dimer were formed, presumably resulting from breakdown of saturated tetramer. The results of this analysis by paper chromatography also indicated the presence of endopectate lyase enzymes.

Studies of polygalacturonase activity. The decrease in viscosity was related to the increase in reducing groups in the assay of polygalacturonase activity of C. felsineum NCIBI0690 (Fig. 2). No unsaturated groups were formed. Similar results were obtained for an enzyme preparation from $C$. felsineum NCIB9540. At $50 \%$ decrease in viscosity, the percentage degradation of the substrate, calculated from the increase in reducing groups, was approximately $0.8 \%$, consistent with endopolygalacturonase activity. Low molecular weight oligomers could not be detected in early samples of the reaction mixture when about $2 \%$ of 


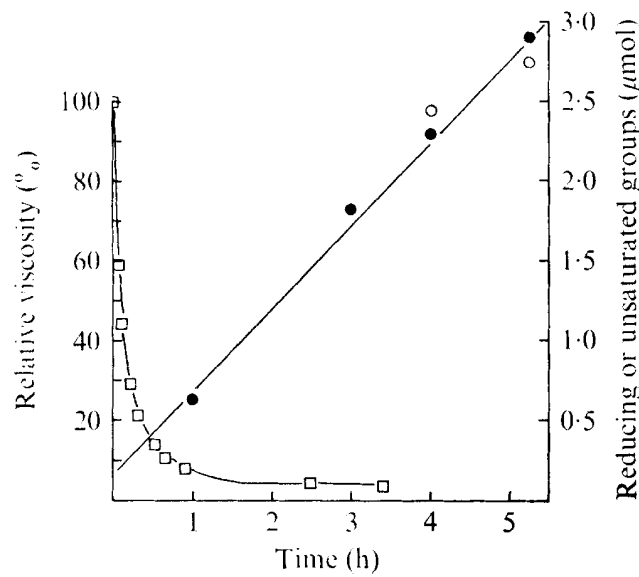

Fig. I

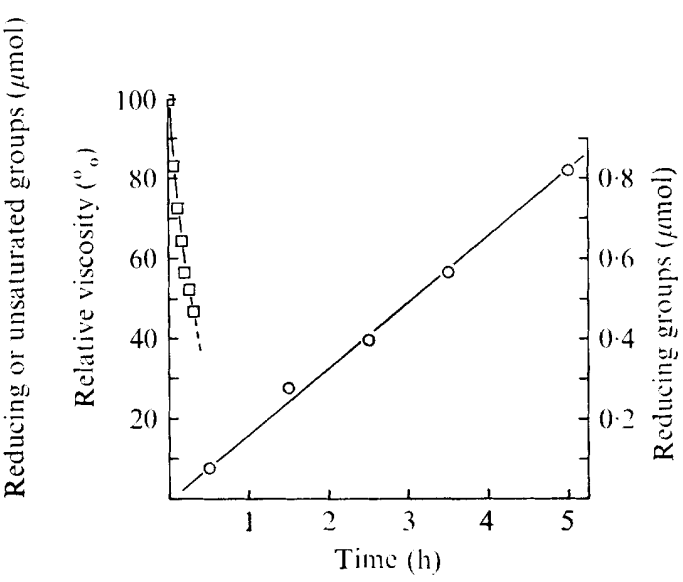

Fig. 2

Fig. I. Decrease in viscosity of pectate and formation of unsaturated and reducing groups by pectate lyase of Clostridium BL70/20. The reaction mixture contained: sodium pectate, $0.5 \%(\mathrm{w} / \mathrm{v})$; $\mathrm{CaCl}_{2} .2 \mathrm{H}_{2} \mathrm{O}, 0.4 \mathrm{~mm}$; and $0.05 \mathrm{M}-\mathrm{Tris} / \mathrm{HCl}$ buffer, $\mathrm{pH} 8.6$. The reaction temperature was $30^{\circ} \mathrm{C}$. The initial flow time of the reaction mixture through the viscometer was $98.6 \mathrm{~s}$ (relative viscosity $100 \%$ ) and the flow time of water was $25.7 \mathrm{~s}$ (relative viscosity $0 \%$ ). $\square$, Relative viscosity; 0 , reducing groups; $\mathbf{O}$, unsaturated groups.

Fig. 2. Decrease in viscosity of pectate and formation of reducing groups by polygalacturonase of Clostridium felsineum NCIBI0690. The reaction mixture contained: sodium pectate, $0.3 \%(\mathrm{w} / \mathrm{v})$; $\mathrm{NaCl}, 0 . \mathrm{I} \mathrm{M}$; and $0.025 \mathrm{M}$-sodium acetate buffer, $\mathrm{pH} 5.2$. The reaction temperature was $30{ }^{\circ} \mathrm{C}$. The initial flow time of the reaction mixture through the viscometer was $52 \cdot 2 \mathrm{~s}$ (relative viscosity $100 \%$ ) and the flow time of water was $25.8 \mathrm{~s}$ (relative viscosity $\circ \%$ ). $\square$, Relative viscosity; $\bigcirc$, reducing groups.

the pectate had been degraded. In samples removed after a reaction time of $15 \times$ longer than that required for $50 \%$ decrease in viscosity, 14 to $15 \%$ of the pectate had been degraded and small amounts of saturated dimer and trimer were detected on chromatograms. In samples removed after $24 \mathrm{~h}, 39 \%$ of the pectate had been degraded. The major oligomers detected were saturated dimer and trimer (and also monomer in the case of C. felsineum NCIB9540); small amounts of tetramer, pentamer and hexamer were also present. The results of these analyses suggest the presence of both exo- and endopolygalacturonase.

\section{Pectic enzymes produced by Clostridium $\mathrm{BL} 70 / 20$ grown in pectate medium}

Assays of an enzyme preparation using the cup-plate method showed lyase but not hydrolase activity. When assayed by the viscometric method at $\mathrm{pH} 8 \cdot 6$, the lyase was more active on pectate than on pectin N.F. A $50 \%$ decrease in viscosity corresponded to $0.2 \%$ degradation of pectate, calculated from the increase in $E_{235}$. The degradation products of the pectate lyase were similar to those formed by the enzyme preparation from this organism grown in potato tissue. These results indicate that the enzyme formed in pectate medium was similar to that formed in potato tissue and was an endopectate lyase. The optimum $\mathrm{pH}$ for pectate lyase activity in viscometric assays was about $\mathrm{pH} 9.5$ in a glycine/ $\mathrm{NaOH}$ buffer. At $\mathrm{pH} 8.5$ and $\mathrm{pH}$ 10.5 the enzyme activity was about $60 \%$ and $55 \%$ of the maximum respectively. At $\mathrm{pH} 6.5$ the enzyme activity was only about $8 \%$ of the maximum. 


\section{DISCUSSION}

The pectic enzymes which are formed by micro-organisms in plant tissue may differ from those formed in culture media (Bateman \& Millar, 1966). For most of this work the cultures were grown in potato tissue in order to induce formation of enzymes important in the maceration of that tissue.

Screening of enzyme preparations by the cup-plate assays divided the organisms into two groups according to their type of pectic enzyme. Group I consisted of the potato isolates and $C$. aurantibutyricum, and group 2 consisted of $C$. felsineum and $C$. roseum NCIB653. The probability that only hydrolase activity was assayed in the plates at $\mathrm{pH} 5.2$ was supported by enzyme preparations from the group I clostridia failing to show any activity at this $\mathrm{pH}$. The enzyme activity on cup-plates at $\mathrm{pH} 8.6$ was probably due mainly to pectate lyase, but possibly the hydrolase enzymes of the group 2 clostridia were also active at this $\mathrm{pH}$.

With the pectate lyase enzymes from all six bacteria, the amount of degradation of substrate causing a $50 \%$ decrease in viscosity was less than $2 \%$. As the substrate is highly polymerized we conclude that the enzymes are of the endo-type, acting randomly on the substrate (Rombouts \& Pilnik, I972). Supporting this, low molecular weight oligomers were absent when I to $4 \%$ of the pectate had been degraded but were present after 12 to $23 \%$ breakdown. Furthermore, with strains BL $70 / 20$, BL $72 / 60$ and C.aurantibutyricum, unsaturated trigalacturonic acid and unsaturated and saturated tetragalacturonic acids were formed before unsaturated and saturated digalacturonic acids. The failure to detect formation of unsaturated and saturated dimer by strain BL72/6I and strains of C. felsineum may indicate the absence of enzymes degrading tetragalacturonic acid. The saturated tetragalacturonic acid was probably the accumulation of fragments from the non-reducing ends of pectate molecules.

The low percentage degradation of the substrate corresponding to $50 \%$ reduction of viscosity by polygalacturonase of $C$. felsineum indicated endopolygalacturonase activity. This was supported by low molecular weight products being first detected when $14 \%$ of the pectate had been degraded, although initial detection of saturated di- and trigalacturonic acids, followed later by higher oligomers, suggested an exopolygalacturonase.

Several workers have studied the pectic enzymes of $C$. felsineum strains. A strain of C. felsineum var. sikokianum formed a large amount of an endopolygalacturonase and low levels of an exopolygalacturonase. The endopolygalacturonase degraded polygalacturonic acid to give mono- and digalacturonic acids and low molecular weight polygalacturonic acid, which was degraded by the exopolygalacturonase forming mono- and digalacturonic acids (Kaji \& Anabuki, 1955; Kaji, 1956, 1959; Kaji et al., 1959). A culture of $C$. felsineum grown with pectin formed a hydrolytic enzyme, active at $\mathrm{pH} 4 \cdot 0$, with a greater activity on pectin than on pectate, and small amounts of pectinesterase (Osman, Abdel-Fattah \& Adbel-Samie, 1969; Abdel-Fattah et al., 1971). Another strain of $C$. felsineum, grown with lactose and beet pectin, formed both an endopolygalacturonase and an endopectate lyase but no pectinesterase (Rodionova, Kapitonova \& Feniksova, 1972) and a further strain formed a 'macerating factor', a polygalacturonase and a pectinesterase when grown on potato pulp, but formed only the first two enzymes when grown on glucose or sucrose (Voznyakovskaya, Avrova \& Andronikashvili, I974).

The ability of $C$. felsineum to form both endo- and exopolygalacturonase, reported by Kaji \& Anabuki (I955), is consistent with our results. Our failure to detect pectinesterase in enzyme preparations from this organism is not surprising in view of the differing reports and the dependence on the culture medium for expression of activity.

Clostridium roseum should now be regarded as C. felsineum (G. Hobbs, personal communication), a view supported by our present results with $C$. roseum NCrB653. 


\section{REFERENCES}

Abdel-Fattah, A. F., Mabrouk, S. S. \& Edrees, M. (197I). Degradation of flax pectin by polygalacturonase of Clostridium felsineum and some aspects of the detection of pectin-methylesterase. Journal of General and Applied Microbiology $\mathbf{1 7}$, 421-427.

Barnes, E. M., Impey, C. S. \& GoldberG, H. S. (1966). Methods for the characterization of the Bacteroidaceae. In Identification Methods for Microbiologists, part A, pp. 5I-58. Edited by B. M. Gibbs and F. A. Skinner. London: Academic Press.

Bateman, D. F. \& Millar, R. L. (1966). Pectic enzymes in tissue degradation. Annual Review of Plant Pathology 4, 1 19-146.

Breed, R. S., Murray, E. G. D. \& Smith, N. R. (editors) (1957). Bergey's Manual of Determinative Bacteriology, 7 th edn. London: Balliere, Tindall \& Cox.

Dingle, J., Reid, W. W. \& Solomons, G. L. (I953). The enzymic degradation of pectin and other polysaccharides. II. Application of the 'cup-plate' assay to the estimation of enzymes. Journal of the Science of Food and Agriculture 4, I49-I 55.

Fogarty, W. M. \& Ward, O. P. (1974). Pectinases and pectic polysaccharides. Progress in Industrial Microbiology 13, 59-1 I9.

Gomorı, G. (1955). Preparation of buffers for use in enzyme studies. Methods in Enzymology 1, 1 38-146.

Hasegawa, S. \& Nagel, C. W. (I962). The characterization of an $\alpha, \beta$-unsaturated digalacturonic acid. Journal of Biological Chemistry 237, 619-621 .

Hellinger, E. (1947). Clostridium aurantibutyricum (n.sp.): a pink, butyric acid Clostridium. Journal of General Microbiology 1, 203-2 IO.

Horikoshi, K. (1972). Production of alkaline enzymes by alkalophilic micro-organisms. Part III. Alkaline pectinase of Bacillus No. P-4-N. Agricultural and Biological Chemistry 36, 285-293.

JANSEN, E. F. \& MACDONNEL, L. R. (1945). Influence of methoxyl content of pectic substances on the action of polygalacturonase. Archives of Biochemistry 8, 97-I I 8.

KAJI, A. (I 956). Studies of macerating enzyme acting on middle lamella pectin. I. Separation of the macerating enzyme produced by Clostridium felsineum var. sikokianum. Bulletin of the Agricultural Chemical Society of Japan 20, 8-1 2.

KAJI, A. (I959). Studies of macerating enzyme acting on middle lamella pectin. IV. Action of macerating enzyme on pectic substances. Bulletin of the Agricultural Chemical Society of Japan 23, I 3 I-I 36.

KaJI, A. \& ANABUKI, Y. (I955). On the purification and properties of bacterial polygalacturonase. Journal of the Agricultural Chemical Society of Japan 29, 775-780.

Kaji, A., Tachibana, S., Aimara, S. \& Anabuki, Y. (1959). Studies on macerating enzyme. V. Separation of pectic enzymes by zone electrophoresis. Technical Bulletin of the Faculty of Agriculture of Kagawa University II, 248-254.

LUND, B. M. (1972). Isolation of pectolytic clostridia from potatoes. Journal of Applied Bacteriology $35,609-6 \mathrm{I} 4$.
Lund, B. M. \& KeLMAN, A. (I977). Determination of the potential for development of bacterial soft rot of potatoes. American Potato Journal 54, 2 I I-225.

Macmillan, J. D. \& VaughN, R. G. (1964). Purification and properties of a polygalacturonic acid trans-eliminase produced by Clostridium multifermentans. Biochemistry 3, 564-572.

McСomb, E. A. \& MCCrEADY, R. M. (I958). Use of the hydroxamic acid reaction for determining pectinesterase activity. Stain Technology 33, 129I3I.

Moran, F., NAsuno, S. \& Starr, M. P. (I968). Extracellular and intracellular polygalacturonic acid trans-eliminases of Erwinia carotovora. Archives of Biochemistry and Biophysics 123, 298-306.

NAGEL, C. W. \& VAughN, R. H. (1962). Comparison of growth and pectolytic enzyme production by Bacillus polymyxa. Journal of Bacteriology 83, I-5.

Nasuno, S. \& Starr, M. P. (1966). Polygalacturonase of Erwinia carotovora. Journal of Biological Chemistry 24r, 5298-5306.

Osman, H. G., Abdel-Fattah, A. F. \& AbdelSAmie, M. (1969). Bacterial pectolytic enzymes. I. Isolation of Clostridium felsineum from the retting water of Egyptian flax, separation and pectolytic activity of its polygalacturonase. Journal of Chemistry of the UAR 12, 543-550.

Roboz, E., Barratt, R. W. \& Tatum, E. L. (1952). Breakdown of pectic substances by a new enzyme from Neurospora. Journal of Biological Chemistry I95, 459-47I.

Rodionova, N. A., Kapitonova, L. S. \& Feniksova, R. B. (1972). Macerating enzymes of Clostridium felsineum. Doklady Akademii Nauk SSSR 207, 466-468. Cited in Chemical Abstracts 78, 9442 I y (1973).

Rombouts, F. M. (1972). Occurrence and properties of bacterial pectate lyases. Ph.D. thesis, Agricultural University, Wageningen, The Netherlands.

Rombouts, F. M. \& Pilnik, W. (1972). Research on pectin depolymerases in the sixties, a literature review. CRC Critical Reviews in Food Technology 3 , I-26.

RudD-Jones, D. \& Dowson, W. J. (I950). On the bacteria responsible for soft rot in stored tubers and the reaction of the tuber to invasion by Bacterium carotovorum (Jones) Lehmann \& Neumann. Annals of Applied Biology 37, 563-569.

Swoboda, P. A. T. \& Lea, C. H. (1958). Determination of the peroxide value of edible fats by colorimetric iodometric procedures. Chemistry and Industry, I090-109I.

Trevelyan, W. E., Procter, D. R.\& Harrison, J. S. (I950). Detection of sugars on paper chromatograms. Nature, London 166, 444-445.

VozNyakovskaya, YU M., AVRova, N. P. \& ANDRONIKASHVILI, E. D. (I974). Reproduction and synthesis of pectolytic enzymes by Clostridium felsineum on media with various carbon sources. Mikrobiologiya 43, 423-427.

WARREN, L. (1960). Thiobarbituric acid spray reagent for deoxy sugars and sialic acids. Nature, London 186, 237. 